\title{
FUZZY-DEA MODEL FOR MEASURING THE EFFICIENCY OF TRANSPORT QUALITY
}

\author{
Pamučar S. Dragan, University of Defence, \\ Military Academy, Deanery, Belgrade \\ FIELD: Mathematics (Operations Research)
}

\begin{abstract}
:
Data envelopment analysis (DEA) is becoming increasingly important as a tool for evaluating and improving the performance of manufacturing and service operations. It has been extensively applied in performance evaluation and benchmarking of schools, hospitals, bank branches, production plants, etc. DEA enables mathematical programming for implicit evaluation of the ratio between a number of imput and output performance parameters. The result is quantification of the efficiency of business opportunities and providing insight into some flaws from the level of top management. Levels of efficiency determined under the same parametres make this analytical process objective and allow for the application of best practices based on the assessment of the overall efficiency. This paper presents a fuzzy-DEA model for evaluating the effectiveness of urban and suburban public transport-USPT. A fuzzy-DEA model provides insight into the current transport quality provided by USPT and proposes for the improvement of inefficient systems up to the level of best standards possible. Such quantification makes long-term stability of USPT possible. Since most of the acquired data is characterized by a high degree of imprecision, subjectivity and uncertainty, fuzzy logic was used for displaying them. Fuzzy linguistic descriptors are given in the output parameters of DEA models. In this way, fuzzy logic enables the exploitation of tolerance that exists in imprecision, uncertainty and partial accuracy of the acquired research results.
\end{abstract}

Key words: Data envelopment analysis (DEA), fuzzy logic, public transport, transport quality.

\section{Introduction}

The significance and role of urban and suburban public transport of passengers (USPT) has an irreplaceable function in the lives of citizens, economy and all activities within a city. The quality of transport service of the system affects the efficiency of production, suppor-

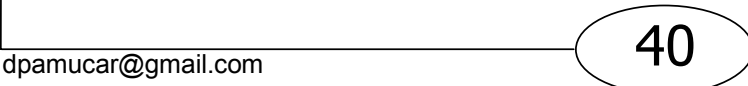


ting processes and other activities of people in the city. The role of local authorities in these processes is crucial, as they are obliged to create conditions for long-term stability of the USPT systems. A system should also be allowed to develop under controlled conditions to realise the required quality as the only true indicator of its success.

A USPT system is a business that requires large resources, funds for vehicles, employees, facilities and equipment, energy and the like; therefore, it is of crucial interest for the economy of cities and the country as a whole to have each USPT company operating immaculately. However, an even greater priority is to ensure greater efficiency of the system and also to provide conditions for the quality of transport service to rise to a higher level and meet the required quality requirements. Namely, the urban and suburban public transport of passengers is not profitable, as it possesses no standard economic characteristics, primarily due to the fact that it is a public service. Holders of the USPT activities are public companies owned by local or regional authorities. In this case, the missing funds to the level of cost - the cost of operating the current business as well as the required financial resources for development are provided primarily via state subsidies.

Generally speaking, USPT systems enjoy high subsidies and grants in Serbian cities, so that 20 to $80 \%$ of the ongoing costs of the system operation is covered by the price of the service and the rest is provided from other sources. Investments, as a rule, are covered from the local, regional and central governments whose interests are to have the investment implemented quality closer or equal to the required. The difference in the nature of public transportation in larger and smaller cities should, however, be emphasized. In larger cities, the urban public transport taking place in the continuous built-up areas is much more prominent compared to the urban transport. On the other hand, in smaller towns suburban transport is more dominant, organized as part of local and intercity transportation. Suburban transportation that connects suburbs with the city centre has the same function as the urban public transport in the inner-city area, primarily because it enables commuting to work, school, etc. Such transport has far-reaching socio-economic significance, since residents live in small suburban areas, mostly in their own homes, and work or study at the very centre which is a continuously developed urban area, in this way not overloading the infrastructure. Since there is a tendency to develop medium size cities in Serbia (70,000 to 350,000 inhabitants) mainly working in the industrial and services sectors, primarily due to the intensive construction of roads or the general standard of the population increase, there is a socio-economic interest to treat suburban public transport as urban. The tendency is to organise and implement a modern integrated system of urban and suburban public transports of passengers that will allow rising the quality of service, an instigator for the development of studies that have analysed the efficiency of USPT for medium size cities in Serbia. 
The paper presents the measurements of the current performance of the required quality of USPT services in cities using a fuzzy-DEA model. The aim of the paper is to use the DEA for gaining insight into the current state of quality of service delivered by the USPT system and making proposals to improve inefficient USPT systems up to the level of its best standards.

\section{Relevant references}

The DEA is a method based on linear programming, which is becoming an increasingly popular management tool. It is commonly used to evaluate the efficiency of a number of 'units' such as a group of producers, banks, or hospitals characterized by multiple inputs and outputs. In fact, the DEA is suitable for evaluating almost any relatively homogeneous set of units, but nowadays it is also recognized as a decision-making aid in multi-criteria analyses of discrete alternatives. The concept of DEA methodology makes it suitable for successful application in the manufacturing and service organisations. Due to its application flexibility, the DEA has inspired many authors to investigate the efficiency of transport.

The idea of measuring efficiency was developed by Farrell in the mid-twentieth century when he used non-parametric approach efficiency limits for measuring efficiency as a relative distance from the border efficiency [9]. This measure, referred to as empirical or relative efficiency was later expanded, especially in the work of Charnes, Cooper and Rhodes [4]. They called this technique Data Envelopment Analysis or DEA. The non-parametric advantage of the DEA has become increasingly popular in businesses that require the definition of a number of input and output parameters of efficiency. A business analysis based on one criterion has been used as the primary method for measuring efficiency in the past. However, as Kemp's papers suggest, one of the evident dilemmas is how to display the standards of comparison when there are a number of criteria[28]. One measure is rarely enough to measure efficiency. Financial indicators of the relationship between the individual outputs and inputs, such as Return on Investment (ROI) and Return on Sales (ROS) can be used as indicators that characterize the financial impact. However, they do not meet the requirements when best practices are sought for and are not sufficient to measure efficiency.

It is important to mention the work of Su and Rogers [22]. This paper presents the years of traffic efficiency studying in countries that are members of the Organization for Economic Cooperation and Development (OECD), using the Data Envelopment Analysis to assess the grade of efficiency. The analysis includes variables associated with conducted tran- 
sportation, added value, economic contributions and carbon dioxide. The analysis provides annually efficiency scores for each country, proposals to improve the efficiency of individual countries and consideration of factors that influence the efficiency of the transportation system.

In addition to the research conducted by Su and Rogers [22], other significant research has been conducted by Duygun, Jackson and Weyman [8]. The paper was inspired by the liberalization movement in European air traffic that began in the late 80's. According to [8], in numerous surveys, primarily by Windle and Good, the efficiency of carriers has been compared, proving that the air carriers in the liberal U.S. market were more efficient than their colleagues in the European market which is regulated more strictly. Bailey noted that the reform of regulations in the USA increased competition, lowered prices and provided significant benefits to users [1]. Evident benefits of American liberalisation and actual inefficiency of the European carriers forced the European Commission to introduce certain reforms in order to promote competition and thus increase the efficiency of European carriers.

Oum and $\mathrm{Yu}$ used the DEA to estimate efficiency in the analysis of the impact of certain variables on the efficiency of the European railroads [17]. The DEA helped Kerstens to estimate the performance of the French urban public transport companies [13]. In the same manner, Gillen and Lall analysed the efficiency of airports [10].

The procedure in most of these studies included two steps. The first step was to measure the efficiency and efficiency distribution in certain times and establish procedures and in the second the Tobit model was used in order to explain the impact of descriptive parameters of efficiency (the parameters that cannot be quantified) on the efficiency of operations.

In the next section, a proceeding from the relevant theoretical approaches, a fuzzy-DEA model for measuring the efficiency of a USPT was developed. The aforementioned model will be shown in the following section of the paper.

\section{Fuzzy-DEA model}

Transportation planning, organisation and management of traffic and transport processes are associated with making certain decisions. Depending on the context of the problems in certain cases highly precise input and output data are available. In such situations, provided that there is an adequate model that can help the decision-maker, favourable solution will result from the decision. However, there is often uncertainty in the data necessary for making certain decisions and decisions are often made based on experience, intuition and subjective evaluation of certain parameters by the decision-maker. 
It is important to point out that the subjective evaluation of certain traffic parameters varies from passenger to passenger, the decision-maker to decision-maker. Thus, at the stage of mathematical modelling of traffic processes whose parameters are not sufficiently certain, uncertain or subjectively estimated, it is necessary to use mathematical methods to treat uncertainty, imprecision or subjectivity in a satisfactory way.

While researching the quality of USPT services a problem appeared concerning quantification of the output parameters: reliability, ride comfort, equipment and organization of stations, as well as staff friendliness and tidiness.

For quantification of these parameters the theory of fuzzy sets was used as the most appropriate mathematical apparatus for handling uncertainty, subjectivity and imprecision. The fuzzy-DEA model is shown in Fig. 1.

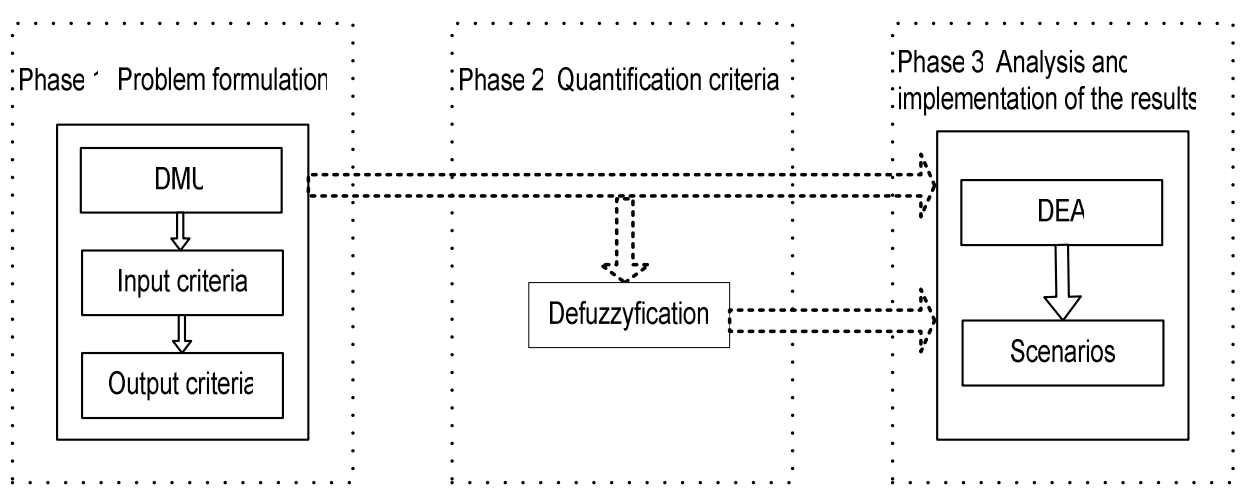

Figure 1 - Fuzzy-DEA methodology

The optimization of choice by the application of fuzzy logic in practice has been applied many times [2, 18, 7, 15]

Phase 1. The first phase includes the selection of DMU whose efficiency is measured that is, the choice of decision-making units. It is necessary that the units whose efficiency is analysed refer to the same organization unit and special care should be taken not to model incomparable units in the decision making process. In special cases, decision making units can belong to different areas or sectors. Then, the effectiveness of common business processes and activities for different areas or sectors within specific functional groups of the organization are measured and compared.

After this, input and output parameters of efficiency of the selected decision making units are defined. The parameters are defined based on theoretical and practical experiences from the given area, depending on the particular business requirements. It is necessary to define the representative parameters, i.e. parameters that best present the activities and processes to which they refer. Good input and output parameters reliably represent all the resources (material, personnel, financial and informa- 
tion) used by the decision-makers, as well as all the business results of the unit. If the parameters are not well allocated, the results may indicate the superficial interpretation as well as partially correct and incorrect conclusions regarding the efficiency of decision making units observed. What is also important is that the values of the defined parameters are obtained from reliable sources and references and are consistent for all the compared units. The DEA approach does not require knowledge of specific functional forms among the input and output parameters, unlike other traditional statistical approaches. The advantage of the DEA is the possibility to consider multiple input and output parametres that are diverse and expressed in different measurement units.

Phase 2. The second phase includes the quantification of input and output parametres using the fuzzy logic and defuzzyfication - projection of the linguistic variables values in real numbers. In designing the fuzzy sets the main question is how to choose the membership function $\mu_{A}(x)$. This function shows to what extent $x \in X$ meets the requirement of belonging to the set of $A$. For the membership function it has to be that $0 \leq \mu_{A}(x) \leq 1$, for every $x \in A$, i.e. $\mu_{A}: X \rightarrow[0,1]$. Formally speaking, the fuzzy set $A$ is defined as a set of ordered pairs

$$
A=\left\{\left(x, \mu_{A}(x)\right) \mid x \in X, 0 \leq \mu_{A}(x) \leq 1\right\}
$$

Triangular fuzzy numbers with membership functions (Fig. 2) are used in this paper.

Triangular fuzzy numbers are usually given in the form $A=\left(a_{1}, a_{2}, a_{3}\right)$, where $a_{2}$ is the value at which the membership function of the fuzzy number is 1.0, $a_{1}$ is the left distribution of the confidence interval and $a_{3}$ is the right distribution of the confidence interval for the fuzzy number $A$.

The membership function of the fuzzy number $A$ is defined as:

$$
\mu_{A}(x)=\left\{\begin{array}{cl}
0, & x<a_{1} \\
\frac{x-a_{1}}{a_{2}-a_{1}}, & a_{1} \leq x \leq a_{2} \\
\frac{a_{3}-x}{a_{3}-a_{2}}, & a_{2} \leq x \leq a_{3} \\
0, & x>a_{3}
\end{array}\right.
$$




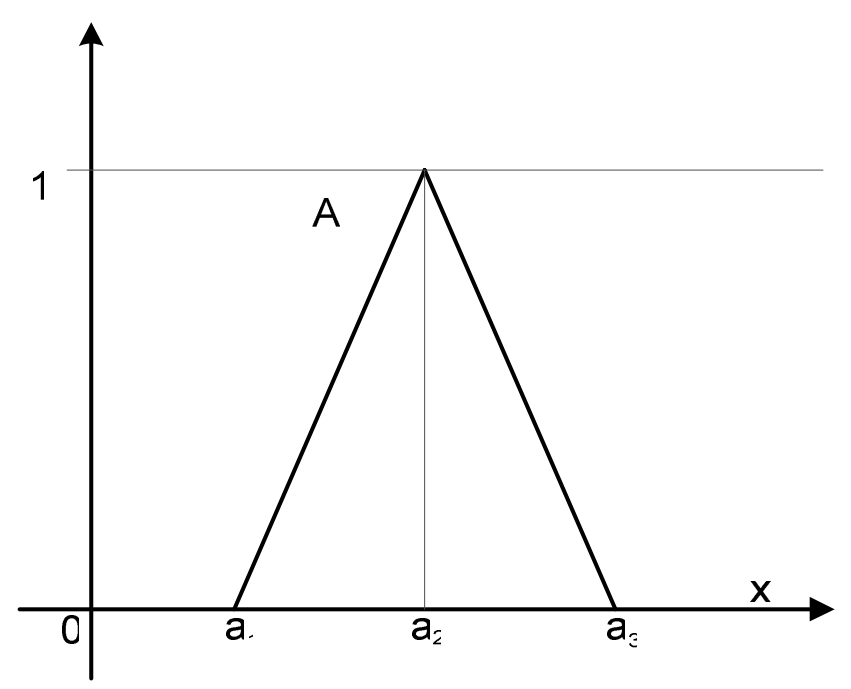

Figure 2 - Triangular fuzzy number

The values of the output parameters that describe the quality of USPT presented as a set of linguistic descriptors $S=\left\{l_{1}, l_{2}, \ldots, l_{n}\right\}, i \in H=\{0,1, \ldots, T\}$, where $T$ is the overall number of linguistic descriptors. The number of linguistic descriptors is $T=5$ : very low $-\mathrm{VL}$, low $-\mathrm{L}$, medium $-\mathrm{M}$, high $-\mathrm{H}$ and very high $-\mathrm{VH}$ (Fig. 3 ).

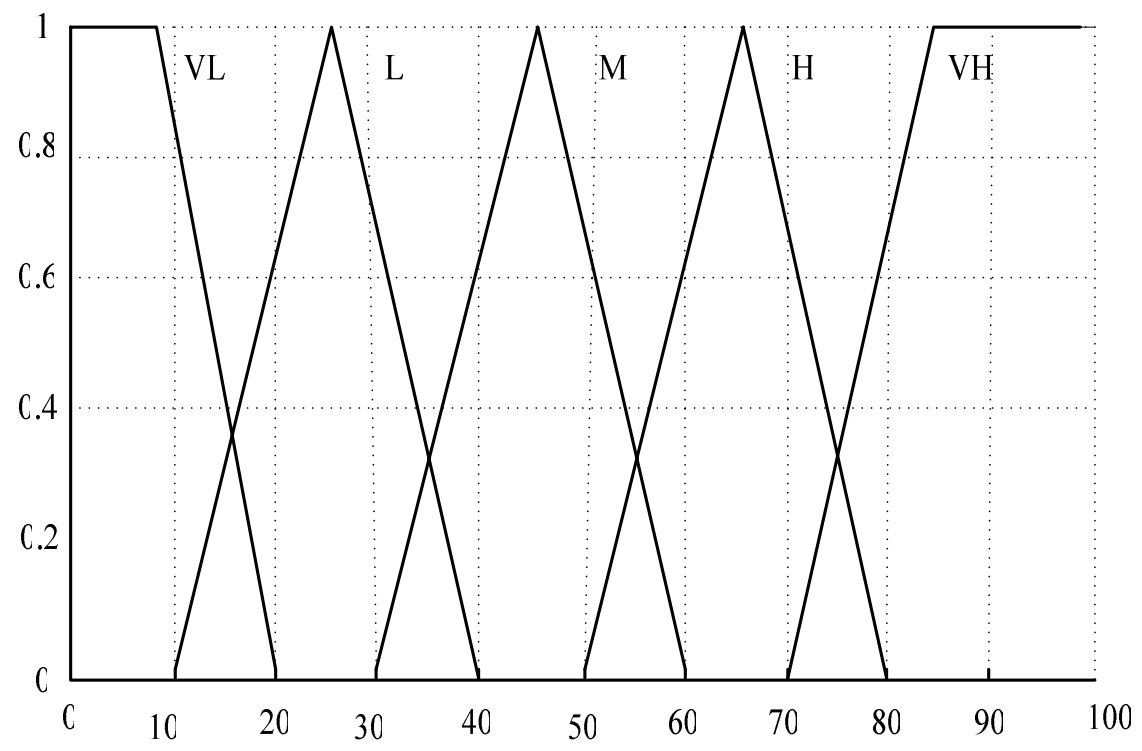

Figure 3 - Graph of linguistic descriptors [2] 
The linguistic descriptors have the following values[2]:

$$
\begin{aligned}
& \mu_{\vartheta_{V L}}=\left\{\begin{array}{cc}
0, & 0 \leq x \\
1, & 0<x \leq 0.85 \\
(2-x) / 1.915, & 0.85<x \leq 2
\end{array}\right\} \\
& \mu_{\Re_{L}}=\left\{\begin{array}{cc}
0, & 1<x \\
x-1, & 1<x<2 \\
1, & 2 \leq x \leq 3 \\
4-x, & 3<x \leq 4 \\
0, & x>4
\end{array}\right\} \\
& \mu_{\rceil_{M}}=\left\{\begin{array}{cc}
0, & 3<x \\
x-3, & 3<x<4 \\
1, & 4 \leq x \leq 5 \\
6-x, & 5<x \leq 6 \\
0, & x>6
\end{array}\right\} \\
& \mu_{\imath_{H}}=\left\{\begin{array}{cc}
0, & 5<x \\
x-5, & 5<x<6 \\
1, & 6 \leq x \leq 7 \\
8-x, & 7<x \leq 8 \\
0, & x>8
\end{array}\right\} \\
& \mu_{\vartheta_{V H}}=\left\{\begin{array}{cc}
0, & 7<x \\
x-7, & 7<x<8.5 \\
1, & x \geq 8.5
\end{array}\right\}
\end{aligned}
$$

The presented fuzzy sets, i.e. the values of the linguistic variables are projected into real numbers. This operation is called defuzzyfication (Fig. 4). For defuzzyfication or the fuzzy number $A=\left(a_{1}, a_{2}, a_{3}\right)$ value projection into real numbers, various methods are used. 


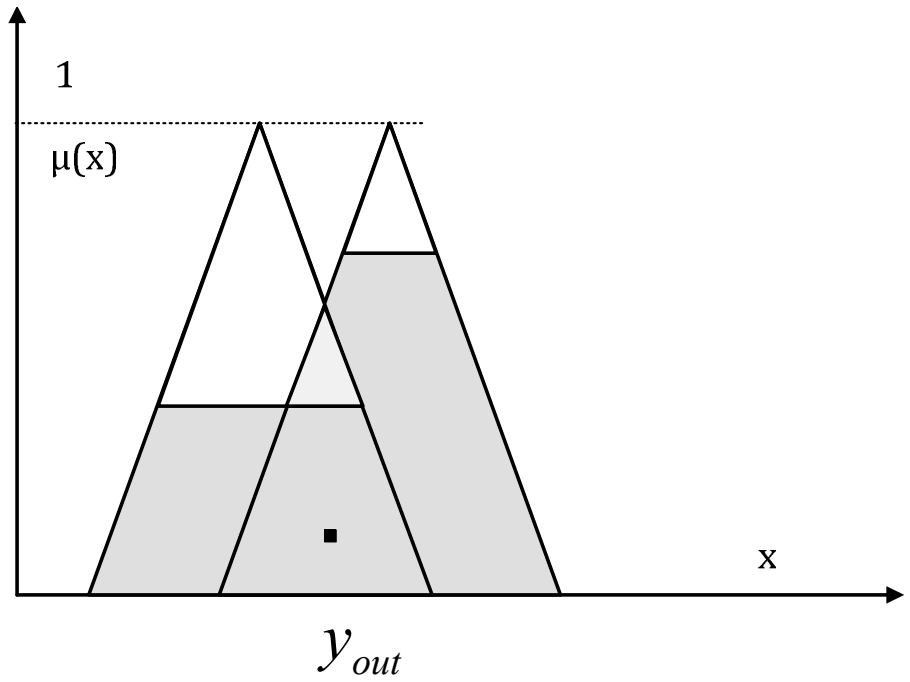

Figure 4 - Defuzzyfication [18]

The centre of gravity method was used in this paper

$$
\text { defazzy } \mathrm{A}=\left[\left(a_{3}-a_{1}\right)+\left(a_{2}-a_{1}\right)\right] \cdot 3^{-1}+a_{1}
$$

The decision making group i.e. representative sample for each of the selected cities comprised $10 \%$ of the population of each using USPT. All participants were entitled to assess once each of the output parameters and decision-making was equal.

Each participant was assigned a set of linguistic descriptors to describe the values of output parameters. This provided as many sets as there were participants in the assessment. Group decision-making differs from single (individual) on methodological and mathematical levels. In case of multiple decision makers it is, as a rule, necessary to apply special techniques in defining, analysing and solving problems. In this case of group decision-making, the group synthesis with complete and incomplete information was applied.

In the case of the group synthesis with complete information, assuming that all members $(e=1,2, \ldots, n)$ of the group $G$ are considered equal in decision making and all have performed evaluation of the optimality criteria for the given hierarchy, all the individual preference scores were aggregated at all levels of the hierarchy according to the expression [18]:

$$
w_{i}=\left[\prod_{j=1}^{n} \lambda_{j} a_{i j}\right]^{1 / n}
$$

where $\lambda_{j}$ represents the preference of the decision maker to the attribute $i$. 
In the case of the group synthesis with incomplete information microaggregation at the position $(i, j)$ in the given matrix is done by the geometric mean of the assessments of those group members who expressed the preference $E_{i}$ compared to the element $E_{j}$. In this case it is necessary to have at least one of the decision makers declare for the value $a_{i j}$. The modification of the previous form yields [18]:

$$
w_{i}^{G}=\left[\prod_{l \in L}^{n} \lambda_{j} a_{i j}(l)\right]^{1 / M}
$$

where $l$ is a set of group members who evaluated the elements couple $\left(E_{i}, E_{j}\right)$ and $M$ is the number of such members.

Phase 3. The third phase involves implementation of the DEA methodology. Business units, their activities or processes are referred to as Decision Making Units (DMU) in the DEA terminology. A DMU is actually a business decision making unit whose efficiency is determined by a set of inputs and outputs and their interdependence, Fig. 5.

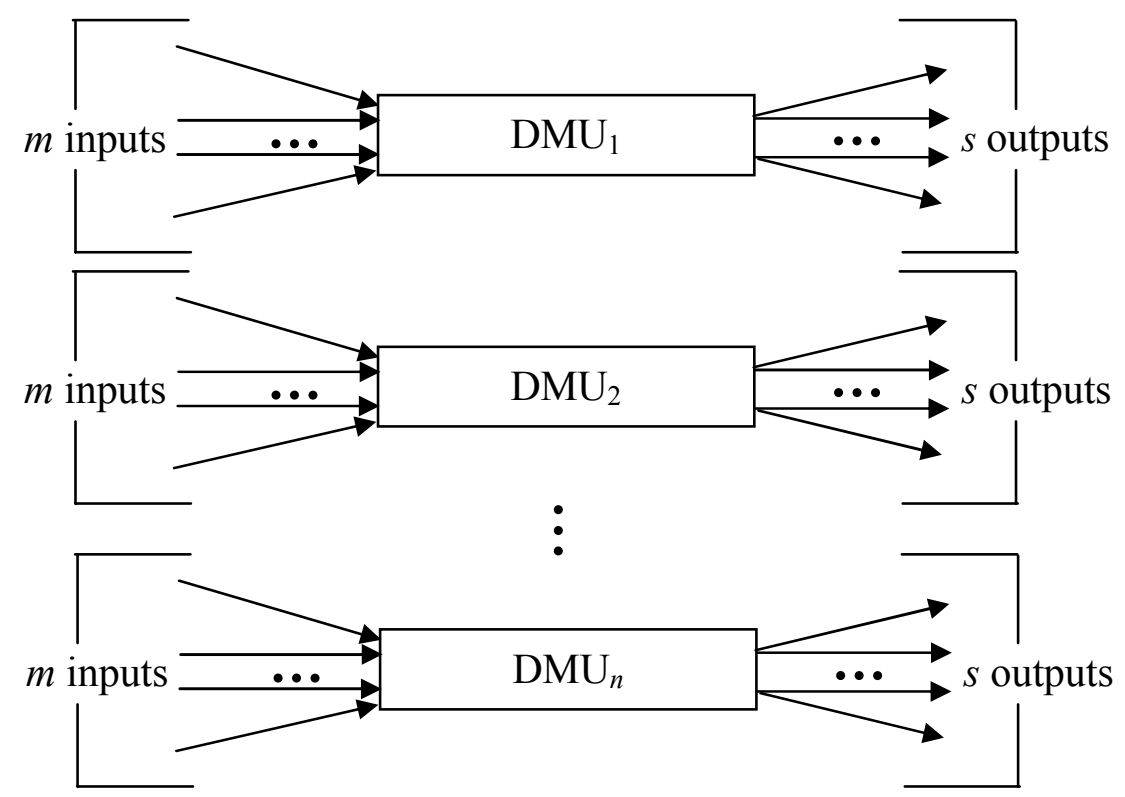

Figure $5-\mathrm{DMUj}$ is determined by $m$ inputs and $s$ outputs 
Decision-making units are compared according to the level of difficulty assessed according to the same parameters and the greater the set of units, the more objective the analytical comparison process is. When calculating efficiency the appropriate DEA model is selected according to the research objectives and designation of the obtained results. The third phase is the actualization of the previous two with the crucial focus on the correct interpretation of the results. In this phase, potential opportunities for business advancement are identified as well as implementation of the defined and selected ameliorations. The main objective of the phase is to strengthen the roots of the imperative of change. It is necessary to thoroughly explore the consequences of the implementation of business ameliorations and integration of knowledge gained in the organization.

This phase allows for the adoption of strategic and management decisions and setting priorities in problem solving. The obtained results and their detailed analysis present numerous possibilities for decision makers to improve their business [19].

\section{Case study application}

The USPT service quality efficiency measuring was conducted in sixteen medium-sized cities in Serbia, Table 2. Based on the theoretical and practical experiences and uniformity of methodology for collecting and presenting data, input/output indicators were selected (Table 1).

The criterion set $K_{i}(i=1, \ldots, 7)$ consists of two subsets:

$-\mathrm{K}^{+}$- subgroup of benefit type criteria, a higher value of the criterion is preferred and

$-\mathrm{K}^{-}$- subset of cost-type criteria, a lower value is preferable.

The values of the input and output parameters are defined according to the studies considered.

Table 1.

Input-output parameters for measuring the efficiency of USPT

\begin{tabular}{|c|c|c|c|c|}
\hline Criteria & Min & Max & Numeric & Linguistic \\
\hline Number of operating vehicles (NOV) & • & & $\bullet$ & \\
\hline Number of drivers (ND) & • & & • & \\
\hline Staff numbers (SN) & $\cdot$ & & $\cdot$ & \\
\hline Reliability - punctuality of arrival (PA) & & • & & • \\
\hline Ride comfort (RC) & & • & & - \\
\hline $\begin{array}{l}\text { Equipment and organization of the } \\
\text { stations (EOS) }\end{array}$ & & • & & • \\
\hline Staff friendliness and tidiness (SFT) & & - & & • \\
\hline
\end{tabular}


Input parameters were originally quantified variables (Table 2).

Table 2

Input parametres of USPT system efficiency.

\begin{tabular}{|l|l|l|l|}
\hline Cities & NOV & ND & SN \\
\hline Novi Sad & 211 & 687 & 1260 \\
\hline Subotica & 87 & 180 & 450 \\
\hline Zrenjanin & 90 & 187 & 395 \\
\hline Nis & 127 & 297 & 832 \\
\hline Vranje & 90 & 250 & 570 \\
\hline Kragujevac & 62 & 149 & 395 \\
\hline Cacak & 105 & 230 & 654 \\
\hline Jagodina & 85 & 234 & 355 \\
\hline Valjevo & 85 & 210 & 405 \\
\hline Loznica & 80 & 180 & 480 \\
\hline Uzice & 85 & 190 & 531 \\
\hline Krusevac & 78 & 210 & 525 \\
\hline Kraljevo & 72 & 198 & 587 \\
\hline Leskovac & 98 & 234 & 532 \\
\hline Pozarevac & 77 & 220 & 550 \\
\hline Novi Pazar & 80 & 204 & 450 \\
\hline
\end{tabular}

Output parametres are linguistic variables quantified using fuzzy logic. These values are considered to be the decision of the group and represent the quantified values of the output parameters of quality efficiency of the service provided by the USPT system (Table 3).

Table 3

Quality efficiency output parameters for the service provided by the USPT system.

\begin{tabular}{|l|l|l|l|l|}
\hline Cities & PA & RC & EOS & SFT \\
\hline Novi Sad & 93 & 80 & 85 & 90 \\
\hline Subotica & 85 & 67 & 85 & 88 \\
\hline Zrenjanin & 91 & 88 & 92 & 94 \\
\hline Nis & 86 & 70 & 75 & 70 \\
\hline Vranje & 60 & 55 & 77 & 49 \\
\hline Kragujevac & 71 & 50 & 55 & 60 \\
\hline Cacak & 91 & 77 & 85 & 87 \\
\hline Jagodina & 88 & 88 & 90 & 91 \\
\hline Valjevo & 76 & 80 & 82 & 84 \\
\hline Loznica & 66 & 61 & 60 & 55 \\
\hline Uzice & 66 & 50 & 52 & 55 \\
\hline Krusevac & 51 & 40 & 55 & 60 \\
\hline Kraljevo & 46 & 35 & 55 & 47 \\
\hline Leskovac & 51 & 50 & 45 & 50 \\
\hline Pozarevac & 51 & 59 & 53 & 51 \\
\hline Novi Pazar & 71 & 70 & 70 & 60 \\
\hline
\end{tabular}


The measure of the USPT efficiency is determined by the output-oriented model based on maximizing the outputs while keeping the inputs at current levels.

$$
\phi^{*}=\max \phi
$$

on condition that:

$$
\begin{aligned}
& \sum_{j=1}^{n} \lambda_{j} x_{i j} \leq x_{i 0}, i=1,2,3, \ldots, m \\
& \sum_{j=1}^{n} \lambda_{j} y_{r j} \geq \phi y_{r 0}, r=1,2,3, \ldots, s ; \\
& \sum_{j=1}^{n} \lambda_{j}=1 ; \lambda_{j} \geq 0, j=1,2,3, \ldots, n
\end{aligned}
$$

USPT $_{0}$ is one of the USPT systems evaluated, where $\mathrm{x}_{i 0}$ and $\mathrm{y}_{r_{0}}$ are the $i^{\text {th }}$ input and the $r^{\text {th }}$ output for $\mathrm{USPT}_{0}$, respectively, while the $\mathrm{USPT}_{0}$ system is efficient if and only if the system evaluation $\phi^{*}=1$ and $\lambda_{j}=0$

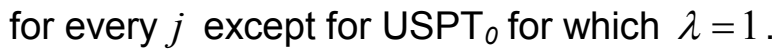

For a full assessment of efficiency the Slack-based model measuring the efficiency using the same data and allowing a full assessment of the inefficient systems was selected.

$$
\max \left(\sum_{i=1}^{m} s_{i}^{-}+\sum_{r=1}^{s} s_{r}^{+}\right)
$$

on condition that:

$$
\begin{aligned}
& \sum_{j=1}^{n} \lambda_{j} x_{i j}+s_{i}^{-}=\theta^{*} x_{i 0}, i=1,2,3, \ldots, m \\
& \sum_{j=1}^{n} \lambda_{j} y_{r j}-s_{r}^{+}=y_{r 0}, r=1,2,3, \ldots, s \\
& \sum_{j=1}^{n} \lambda_{j}=1 ; \lambda_{j} \geq 0, j=1,2,3, \ldots, n
\end{aligned}
$$


Using the Slack-based model makes it possible to determine the margins of the input $s^{-}$(in other words to what extent the input parametres are to be reduced i.e. rationalised) and the output $s^{+}$(how much to increase the output parametres of efficiency resulting from the implemented rationalisation i.e. the actual level of the results increase) for inefficient USPTs for them to achieve the best standards.

\section{Results and discussion}

As given in Table 4, out of 16 USPT systems analysed, five meet the necessary and sufficient conditions of the efficiency ie have the efficiency evaluation and own standard equal to one, while all the other standards $\lambda j=0$ for every $j=1,2,3, \ldots, 16$.

USPT system efficiency evaluation.

\begin{tabular}{|c|c|c|c|c|c|c|c|}
\hline $\begin{array}{c}\text { USPT } \\
\text { systems }\end{array}$ & $\begin{array}{c}\text { VRS } \\
\text { Efficiency }\end{array}$ & \multicolumn{6}{|c|}{ Benchmarks } \\
\hline Novi Sad & 1,00000 & 1,000 & Novi Sad & & & & \\
\hline Subotica & 1,00000 & 1,000 & Subotica & & & & \\
\hline Zrenjanin & 1,00000 & 1,000 & Zrenjanin & & & & \\
\hline Nis & 1,06326 & 0,220 & Novi Sad & 0,780 & Zrenjanin & & \\
\hline Vranje & 1,19481 & 1,000 & Zrenjanin & & & & \\
\hline Kragujevac & 1,00000 & 1,000 & Kragujevac & & & & \\
\hline Cacak & 1,00189 & 0,086 & Novi Sad & 0,914 & Zrenjanin & & \\
\hline Jagodina & 1,00000 & 1,000 & Jagodina & & & & \\
\hline Valjevo & 1,06215 & 0,367 & Zrenjanin & 0,080 & Kragujevac & 0,554 & Jagodina \\
\hline Loznica & 1,23373 & 0,542 & Zrenjanin & 0,335 & Kragujevac & 0,122 & Jagodina \\
\hline Uzice & 1,32625 & 0,672 & Zrenjanin & 0,146 & Kragujevac & 0,182 & Jagodina \\
\hline Krusevac & 1,35942 & 0,304 & Kragujevac & 0,696 & Jagodina & & \\
\hline Kraljevo & 1,27668 & 0,565 & Kragujevac & 0,435 & Jagodina & & \\
\hline Leskovac & 1,76000 & 1,000 & Zrenjanin & & & & \\
\hline Pozarevac & 1,26750 & 0,348 & Kragujevac & 0,652 & Jagodina & & \\
\hline Novi Pazar & 1,11836 & 0,176 & Zrenjanin & 0,256 & Kragujevac & 0,568 & Jagodina \\
\hline
\end{tabular}


The research shows that the USPTs in Nis, Vranje, Cacak, Valjevo, Loznica, Uzice, Kruseavac, Kraljevo, Leskovac, Pozarevac and Novi Pazar are inefficient.

The USPT Nis received the efficiency evaluation $\theta^{*}=1,06326$ and the standards: $\lambda_{1}=0,220 ; \lambda_{3}=0,780\left(\lambda_{3}>\lambda_{1}\right)$. This means that the benchmarks for USPT are Nis, Novi Sad and Zrenjanin.

Based on the results given in Table 4, the following conclusions can be drawn:

- for inefficient USPT systems in Nis, Vranje, Cacak, Loznica, Uzice and Leskoavac the best benchmark is the third USPT system, i.e. the USPT system in Zrenjanin.

- for inefficient USPT systems in Valjevo, Krusevac, Pozarevac and Novi Pazar the best benchmark is the eighth USPT system, i.e. the USPT system in Jagodina and

- for inefficient USPT systems in Kraljevo the best benchmark is the sixth USPT system, i.e. the USPT system in Kragujevac.

The results of the Slack-based models show the boundary values of the input and output parameters for the inefficient systems of USPT.

For the USPT in Nis:

$s_{1}^{-}=37 ; s_{2}^{-}=110 ; s_{3}^{-}=437 ; s_{1}^{+}=5 ; s_{2}^{+}=18, s_{3}^{+}=17$ and $s_{4}^{+}=24$.

For the USPT in Vranje:

$s_{1}^{-}=0 ; s_{2}^{-}=63 ; s_{3}^{-}=175 ; s_{1}^{+}=31 ; s_{2}^{+}=33, s_{3}^{+}=15$ and $s_{4}^{+}=45$.

For the USPT in Cacak:

$s_{1}^{-}=15 ; s_{2}^{-}=43 ; s_{3}^{-}=259 ; s_{1}^{+}=0 ; s_{2}^{+}=11, s_{3}^{+}=7$ and $s_{4}^{+}=7$.

For the USPT in Valjevo:

$s_{1}^{-}=0 ; \quad s_{2}^{-}=0 ; \quad s_{3}^{-}=32,1539 ; \quad s_{1}^{+}=11,74502 ; \quad s_{2}^{+}=4,97211$,

$s_{3}^{+}=5,94422$ and $s_{4}^{+}=5,62948$.

For the USPT in Loznica:

$s_{1}^{-}=0 ; \quad s_{2}^{-}=0 ; \quad s_{3}^{-}=89,88712 ; \quad s_{1}^{+}=17,92696 ; \quad s_{2}^{+}=14,25764$,

$s_{3}^{+}=19,34861$ and $s_{4}^{+}=27,23240$.

For the USPT in Uzice:

$s_{1}^{-}=0 ; \quad s_{2}^{-}=0 ; \quad s_{3}^{-}=143,27756 ; \quad s_{1}^{+}=21,53254 ; \quad s_{2}^{+}=32,44887$,

$s_{3}^{+}=34,23108$ and $s_{4}^{+}=33,48738$. 
For the USPT in Krusevac:

$s_{1}^{-}=0 ; \quad s_{2}^{-}=1,86957 ; \quad s_{3}^{-}=157,82609 ; \quad s_{1}^{+}=31,82609 ;$

$s_{2}^{+}=36,43478, s_{3}^{+}=24,34783$ and $s_{4}^{+}=21,56522$.

For the USPT in Kraljevo:

$s_{1}^{-}=0 ; \quad s_{2}^{-}=12,04348 ; \quad s_{3}^{-}=209,39130 ; \quad s_{1}^{+}=32,39130 ;$

$s_{2}^{+}=31,52174, s_{3}^{+}=15,21739$ and $s_{4}^{+}=26,47826$.

For the USPT in Leskovac:

$s_{1}^{-}=8 ; s_{2}^{-}=47 ; s_{3}^{-}=137 ; s_{1}^{+}=40 ; s_{2}^{+}=38, s_{3}^{+}=47$ and $s_{4}^{+}=44$.

For the USPT in Pozarevac:

$s_{1}^{-}=0 ; \quad s_{2}^{-}=15,56522 ; \quad s_{3}^{-}=181,08696 ; \quad s_{1}^{+}=31,08696 ;$

$s_{2}^{+}=15,78261, s_{3}^{+}=24,82609$ and $s_{4}^{+}=29,21739$.

For the USPT in Novi Pazar:

$s_{1}^{-}=0 ; \quad s_{2}^{-}=0 ; \quad s_{3}^{-}=77,73572 ; \quad s_{1}^{+}=13,18194 ; \quad s_{2}^{+}=8,28552$,

$s_{3}^{+}=11,40438$ and $s_{4}^{+}=23,60292$.

Based on the marginal values, it is necessary to implement a complete rationalisation of the inefficient USPT systems inputs. With such inputs, it is necessary to achieve outputs characterized by the output parameters of reliability (punctuality of arrival), the ride comfort, equipment and organization of the stations and staff friendliness and tidiness, greater than the value of the existing output margins. The benchmarks based on which the rationalisation of the input and output parametres of the inefficient USPTs is performed are shown in Table 4.

\section{Conclusion}

DEA methods of operational research are being increasingly used in the transportation sector, for the comparative analysis of efficiency of entities operating under similar conditions and using the same types of inputs to produce the same kind of outputs. In the case of quality efficiency evaluation of the USPT systems, the DEA method is acceptable as it simultaneously takes into account multiple inputs and outputs and objectively evaluates the relative efficiency.

In all the selected cities, a standard survey on a sample of $10 \%$ of the population using the USPT services was conducted. This means that the presented studies included the service quality in terms of: availability in space and time, services convenience of use and stability. The model 
being open can include even greater number of parameters which would result in more objective assessment of the USPT service quality.

Based on the calculated performance the index value was made. The DMU division into relatively efficient and inefficient ones was performed based on the calculated value of the efficiency index. In addition to the relative efficiency of the USPT systems the DEA identified the benchmark with more efficient USPT which are examples of good operating practice for the inefficient DMU.

The DEA methodology application provides efficient input/output levels display for each inefficient unit with which it would become efficient. Successful implementation of this methodology certainly depends on the quality of the input data, a consistent choice of the input and output parameters used in calculations and requires a dynamic aspect of monitoring, i.e. evaluation of performance for years in a row.

\section{References}

[1] Bailey, T. C., Munford, A. G., Modelling a large, sparse spatial interaction matrix using data relating to a subset of possible flows, European Journal of Operational Research, 3/1994, pp. 489-500.

[2] Božanić, D., Pamučar, D., Evaluating locations for river crossing using fuzzy logic, Military Technical Courier (Vojnotehnički glasnik), Vol. 58, No. 1, pp. 129-145, ISSN 0042-8469, UDC 623+355/359, Belgrade, 2010.

[3] Charnes, A., Cooper, W. W., Lewin, Y., Seiford, L. M., Data envelopment analysis: Theory, methodology and applications, Kluwer Academic Publish, Boston, 1994.

[4] Charnes, A., Cooper, W. W., Rhodes, E., Measuring the efficiency of decision making units, European Journal of Operational Research. 2/1978, pp. 429-444.

[5] Chiclana, F., Herrera, F., Herrera-Viedma, E., Alonso, S., Some induced ordered weighted averaging operators and their use for solving group decisionmaking problems based on fuzzy preference relations, European Journal of Operational Research, 182/2007, pp. 383-399.

[6] Cooper, W. W., Seiford, L. M., Tone, K., Data Envelopment Analysis: A Comprehensive Text with Models, Applications, References and DEA-Solver Software, Kluwer Academic Publishers, Boston, 2000.

[7] Đorović, B., Ljubojević, S., Dimić, S., Optimizing transportation processes using the route model, Military Technical Courier (Vojnotehnički glasnik), Vol. 53, No. 1, pp. 76-85, ISSN 0042-8469, UDC 623+355/359, Belgrade 2005.

[8] Duygun, F. M., Jackson, P. M., Weyman-Jones, T. G., Measuring the efficiency of European Airlines: An application of DEA and Tobit Analysis, AM of the European Public Choice Society, Siena, 2000.

[9] Farrell, M. J., The Measurement of Productive Efficiency, Journal of the Royal Statistical Society, 120/1957, pp. 253-281.

[10] Gillen, D., Lall, A., Developing measures of airport productivity and performance: an application of data envelopment analysis, Transportation Research E: Logistics and Transportation Review, 4/1997, pp. 261-273. 
[11] Herrera, F., Herrera-Viedma, E., Martínez, L., A fuzzy linguistic methodology to deal with unbalanced linguistic term sets, IEEE Transactions on Fuzzy Systems, 16/2008, pp. 354-370.

[12] Karlaftis, M.G., A DEA approach for evaluating the efficiency and effectiveness of urban transit systems, European Journal of Operational Research, 152/2004, pp. 354-364.

[13] Kerstens, K., Technical efficiency measurement and explanation of French urban transit companies, Transportation Research, 30/1996, pp. 431-452.

[14] Liang, L., Wu, J., Cook, W. D., Zhu, J., Alternative secondary goals in $D E A$ cross efficiency evaluation, International Journal of Production Economics, 113/2008, pp. 1025-1030.

[15] Ljubojević, S., Possibilities of implementation of contemporary traffic management systems in the defense system, Military Technical Courier (Vojnotehnički glasnik), Vol. 55, No. 4, pp. 463-474, ISSN 0042-8469, UDC 623+355/359, Belgrade 2007.

[16] Martínez, L., Sensory evaluation based on linguistic decision analysis, International Journal of Approximate Reasoning, 44/2007, pp. 148-164.

[17] Oum, T. H., Yu, C., Economic efficiency of railways and implications for public policy, Journal of Transport Economics and Policy , 28/1994, pp. 121-138.

[18] Pamučar, D., Using fuzzy logic and neural networks during decision making proces in transport, Military Technical Courier (Vojnotehnički glasnik), Vol. 58, No. 3, pp 125-143, ISSN 0042-8469, UDC 623+355/359, Belgrade 2010.

[19] Seiford, L. M., Sensitivity and stability of the classification of returns to scale in data envelopment analysis, Journal of Productivity Analysis, 1/199, pp. 55-75.

[20] Seiford, L. M., Zhu, J., An acceptance system decision rule with data envelopment analysis, Computers and Operations Research, 25/1998, pp. 329-332.

[21] Sherman, D., Zhu, J., Service Productivity Management: Improving service performance using data envelopment analysis (DEA), Springer, Boston, 1996.

[22] Su, J. C. P., Rogers, M. M., Using DEA to Examine Efficiency of National Transportation Systems, 2005.

[23] Thanassoulis, E., Introduction to the Theory and Aplication of Data Envelopment Analysis, Kluwer Academic Publisher, Boston, 2001.

[24] Tone, K., Tsutsui, M., Network DEA: A slacks-based measure approach, European Journal of Operational Research, 197/2009, pp. 243-252.

[25] Wei, Q. L., Sun, B., Xiao, Z. J., Measuring Technical Progress With Data Envelopment Analysis, European Journal of Operational Research, 80(3)/1995, pp. 691-702.

[26] Wilkens, K., Portfolio evaluation and benchmark selection: A mathematical programming approach, Journal of Alternative Investments, 1/2001, pp. 9-19.

[27] Yu, M. M., Fan, C. K., Measuring the Cost Effectiveness of Multimode Bus Transit in the Presence of Accident Risks, Transportation Planning and Technology, 5/2006, pp. 383-407.

[28] Zhu, J., Quantitative models for performance evaluation and benchmarking: data envelopment analysis with spreadsheets and DEA excel solver, Kluwer Academic Publishers, Boston, 2003. 


\title{
FUZZY-DEA MODEL ZA MERENJE EFIKANOSTI KVALITETA TRANSPORTNE USLUGE
}

\author{
OBLAST: matematika (operaciona istraživanja)
}

Rezime:

DEA pristup omogućava da se matematičkim programiranjem implicitno procenjuje odnos većeg broja ulaznih i izlaznih parametara uspešnosti. Rezultat toga je kvantifikacija efikasnosti poslovanja preduzeća i pružanje mogućnosti sagledavanja određenih nedostataka sa nivoa top menadžmenta. Nivoi efikasnosti određeni na osnovu istih parametara ovaj analitički proces čine objektivnim i omogućavaju da se na osnovu procene ukupne efikasnosti uspešno identifikuju primeri najbolje prakse. $U$ radu je prikazan fuzzy-DEA model za ocenu efikasnosti sistema javnog gradskog i prigradskog prevoza. Fuzzy-DEA model omogućava uvid u trenutno stanje pružanja kvaliteta usluga sistema JGPP-a i daje predloge za unapređenje neefikasnih sistema JGPP-a do nivoa svojih najboljih standarda. Takva kvantifikacija omogućuje formiranje dugoročno stabilnog sistema JGPP-a. Pošto većinu prikupljenih podataka karakteriše visok stepen neizvesnosti, subjektivnosti i neodređenosti, za prikaz opisanih neizvesnosti i neodređenosti korišćena je fuzzy logika. Fuzzy lingvističkim deskriptorima opisani su izlazni parametri DEA modela. Na taj način fuzzy logikom omogućena je eksploatacija tolerancije koja postoji pri nepreciznosti, nejasnoći i parcijalnoj istinitosti dobijenih rezultata istraživanja.

Uvod

Značaj i uloga javnog gradskog i prigradskog prevoza putnika (JGPP) je nezamenjiva funkcija u životu svih građana, privrede $i$ svih aktivnosti $u$ gradu. Kvalitet prevozne usluge ovog sistema utiče na efikasnost svih proizvodnih, pratećih procesa i drugih aktivnosti ljudi u gradu. Uloga lokalnih vlasti u ovim procesima je ključna, jer one moraju da stvore uslove za dugoročan stabilan sistem JGPP-a. Pored toga, treba omogućiti da se sistem razvija u kontrolisanim uslovima koji će realizovati zahtevani kvalitet kao jedini pravi pokazatelj njegove uspešnosti. Sistem JGPP-a je delatnost koja angažuje velika sredstva uložena u resurse: vozila, zaposlene, objekte i opremu, energiju i slično, pa je za ekonomiju gradova i državu u celini od interesa da svako preduzeće JGPP-a efikasno funkcioniše i radi. Međutim, za gradove $i$ državu daleko je veći interes kako obezbediti da ovaj sistem funkcioniše bolje, odnosno kako stvoriti uslove da se kvalitet prevozne usluge podigne na viši nivo i približi zahtevanom kvalitetu. Naime, delatnost javnog gradskog $i$ prigradskog prevoza putnika nije profitabilna, jer nema standardne ekonomske karakteristike, pre svega zbog činjenice da se radi o javnoj usluzi. Nosioci delatnosti JGPP-a su javna preduzeća koja su u vlasništvu lokalnih ili regionalnih vlasti. U ovom slučaju, nedostajuća sredstva do nivoa cene koštanja - operativnih tekućih troškova poslovanja preduzeća i potrebnih finansijskih sredstava za razvoj obezbeđuju se pre svega subvencijama države. 
Predmet rada je merenje postojeće efikasnosti zahtevanog kvaliteta usluge sistema JGPP gradova primenom fuzzy-DEA modela. Cilj rada je da se na osnovu DEA dobije uvid u trenutno stanje pružanja kvaliteta usluga sistema JGPP-a ali i davanje predloga unapređenja neefikasnih sistema JGPP-a do nivoa svojih najboljih standarda.

\section{Relevantna literatura}

Koncept DEA metodologije pruža mogućnost da se ova analiza koristi uspešno i u proizvodnim i u uslužnim organizacijama. Zbog svoje fleksibilnosti u primeni DEA je poslednjih godina motivacija mnogim autorima koji istražuju efikasnost saobraćaja.

Ideju merenja efikasnosti razvio je M. J. Farrell sredinom dvadesetog veka kada je koristio pristup neparametarske granice efikasnosti za merenje efikasnosti kao relativne udaljenosti od granice efikasnosti.

Značajno je pomenuti rad Su, J. C. P. i M. M. Rogers [22]. Ovaj rad bavi se istraživanjem višegodišnje saobraćajne efikasnosti zemalja koje su članice Organizacije za ekonomsku saradnju i razvoj OECD (Organization for Economic Cooperation and Development), koristeći analizu obavijanja podataka za određivanje ocena efikasnosti.

Pored istraživanja koje je sproveo Su, J. C. P. i M. M. Rogers, značajno je i istraživanje koje je sproveo Duygun Fethi, M., P. M. Jackson, i T. G. Weyman[8]. Rad je bio inspirisan pokretom liberalizacije $u$ oblasti evropskog avio-saobraćaja koji je otpočeo krajem osamdesetih godina. Prema [14], u brojnim istraživanjima, a najviše Windle-a i Good-a poređena je efikasnost prevoznika i pokazano je da su avioprevoznici na liberalnijem američkom tržištu efikasniji od svojih kolega na evropskom tržištu koje je strože uređeno.

Oum i Yu koristili su DEA da ocene efikasnosti $u$ analizi uticaja određenih promenljivih veličina na efikasnost evropskih železnica [17]. $U$ većini ovih istraživanjima korišćena je procedura u dva koraka. U prvom koraku merile su se efikasnosti i raspodele efikasnosti po određenim periodima i donošenje mera, a u drugom je korišćen Tobit model s ciljem da se objasni uticaj opisnih parametara efikasnosti (parametara koji ne mogu da se kvantifikuju) na efikasnost poslovanja.

$U$ narednom delu rada, polazeći od relevantnih teorijskih pristupa, razvijen je fuzzy-DEA model za merenje efikasnosti sistema JGPP-a. Navedeni model biće prikazan u narednom poglavlju rada.

\section{Fuzzy-DEA model}

Procesi planiranja saobraćaja, organizacije transporta i upravljanja saobraćajem i transportom povezani su sa donošenjem određenih odluka. U zavisnosti od konteksta problema u određenim slučajevima raspolaže se veoma preciznim ulaznim i izlaznim podacima. U takvim situacijama, uz pretpostavku postojanja adekvatnog modela koji donosiocu odluke pomaže u odlučivanju, mogu da se očekuju zadovoljavajuća rešenja koja proističu iz donete odluke. Međutim, često postoji neizvesnost podataka neophodnih za donošenje određenih odluka, često se odluke donose na osnovu iskustva, intuicije i subjektivne procene određenih parametara od strane donosioca odluke. 
Potrebno je istaći da se subjektivne procene pojedinih saobraćajnih parametara razlikuju od putnika do putnika, od donosioca odluke do donosioca odluke. Samim tim u fazi matematičkog modeliranja saobraćajnih procesa čiji su parametri nedovoljno izvesni, neodređeni ili subjektivno procenjeni, neophodno je koristiti matematičke metode koje mogu na zadovoljavajući način da tretiraju neizvesnost, neodređenost ili subjektivnost.

Prilikom istraživanja kvaliteta prevozne usluge JGPP uočen je problem kvanifikacije izlaznih parametara: pouzdanost, komfor $u$ vožnji, opremljenost i uređenost stanica i ljubaznost $i$ urednost osoblja.

Za kvanifikaciju navedenih parametara korišćena je teorija fuzzy skupova koja predstavlja najpogodniji matematički aparat za tretiranje neizvesnosti, subjektivnosti, višeznačnosti i neodređenosti.

\section{Primena opisane metodologije}

Merenje efikasnosti kvaliteta usluge sistema JGPP-a sprovedena je $u$ šesnaest srednjih po veličini gradova u Srbiji (tabela 2). Na osnovu iskustava teorije i prakse $i$ ujednačenosti metodologije prikupljanja i prezentovanja podataka izabrani su ulazno/izlazni pokazatelji (tabela 1).

Skup kriterijuma $K_{i}(i=1, \ldots, 7)$ čine dva podskupa:

- $K^{+}$- podskup kriterijuma benefitnog tipa, veća vrednost kriterijuma poželjnija $i$

- K- podskup kriterijuma troškovnog tipa, manja vrednost poželjnija.

Vrednosti ulaznih i izlaznih parametara definisani su na osnovu istraživanja. Ulazni parametri su izvorno kvantifikovane promenljive $i$ prezentovani su u tabeli 2.

Izlazni parametri su lingvističke promenljive koje su kvantifikovane primenom fuzzy logike. Ove vrednosti smatraju se odlukom grupe $i$ predstavljaju kvantifikovane vrednosti izlaznih parametara efikasnosti kvaliteta pružanja usluge sistema JGPP-a (tabela 3).

Rezultati i diskusija

Rezultati primene Modela 1 dati su u tabeli 4.

Kao što je prikazano u tabeli 4, od šesnaest analiziranih sistema JGPP-a pet ispunjava i potreban i dovoljan uslov efikasnosti, odnosno imaju ocenu efikasnosti i sopstveni standard jednak jedinici, dok su svi ostali standardi $\lambda j=0$ za svako $j=1,2,3, \ldots, 16$.

Istraživanje je pokazalo da JGPP u Nišu, Vranju, Čačku, Valjevu, Loznici, Užicu, Kruševcu, Kraljevu, Leskovcu, Požarevcu i Novom Pazaru nije efikasan.

Za sistem JGPP u Nišu dobijena je ocena efikasnosti $\theta^{*}=1,06326$ $i$ standardi: $\lambda 1=0,220 ; \lambda 3=0,780(\lambda 3>\lambda 1)$. To znači da su benchmarkovi za JGPP u Nišu JGPP u Novom Sadu i JGPP u Zrenjaninu.

Na osnovu rezultata koji su prikazani u tabeli 4 mogu da se izvedu sledeći zaključci:

- za neefikasne sisteme JGPP-a u Nišu, Vranju, Čačku, Loznici, Užicu i Leskovcu najbolji benchmark je treći sistem JGPP-a, odnosno sistem 
JGPP-a u Zrenjaninu;

- za neefikasne sisteme JGPP-a u Valjevu, Kruševcu, Požarevcu i Novom Pazaru najbolji benchmark je osmi sistem JGPP-a, odnosno sistem JGPP-a u Jagodini $i$

- za neefikasne sisteme JGPP-a u Kraljevu najbolji standard je šesti sistem JGPP-a, odnosno sistem JGPP-a u Kragujevcu.

Rezultati Slack-based modela pokazuju granične vrednosti ulaznih i izlaznih parametara za neefikasne sisteme JGPP-a.

Na osnovu dobijenih vrednosti margina neophodno je da neefikasni sistemi JGPP-a izvrše racionalizaciju svojih inputa. Sa takvim inputima neophodno je da ostvare outpute, koji su okarakterisani izlaznim parametrima Pouzdanost (tačnost nailaska vozila), Komfor u vožnji, Opremljenost i uređenost stanica i Ljubaznost i urednost osoblja, veće od postojećih za vrednosti izlaznih margina. Benchmark-ovi po ugledu na koje će neefikasni JGPP-ovi izvršiti racionalizaciju ulaznih i izlaznih parametara prikazani su u tabeli 4.

Zaključak

DEA metoda operacionih istraživanja sve više se koristi, u sektoru transporta, za komparativnu analizu efikasnosti entiteta koji rade pod sličnim uslovima $i$ koriste iste vrste ulaza da bi proizveli iste vrste izlaza. U slučaju ocene efikasnosti kvaliteta sistema JGPP-a, DEA metoda je prihvatljiva jer istovremeno uzima u obzir više ulaza i izlaza i objektivno ocenjuje relativnu efikasnost.

U svim posmatranim gradovima sprovedena je standardna anketa na uzorku od $10 \%$ populacije grada koja koristi usluge sistema JGPP-a. To znači da su navedena istraživanja obuhvatila kvalitet usluge u smislu: pristupačnost u prostoru i vremenu, pogodnost usluge za korišćenje i stabilnost usluge. Pošto je model otvoren moguće je uključiti i veći broj parametara što bi rezultiralo objektivnijem merenju kvaliteta usluge sistema JGPP-a.

$\mathrm{Na}$ osnovu izračunate vrednosti indeksa efikasnosti izvršena je podela DMU-ova na relativno efikasne i neefikasne. Primenom DEA, pored relativne efikasnosti sistema JGPP-ova, identifikovani su benčmarkovi sa efikasnim sistemima JGPP-a, a koji pružaju primer dobre operativne prakse za neefikasni DMU.

Primenom DEA metodologije prikazani su efikasni ulazno/izlazni nivoi za svaku neefikasnu jedinicu sa kojima bi ona postala efikasna. Uspešna primena ove metodologije svakako zavisi od kvaliteta ulaznih podataka, usaglašenog izbora ulaznih i izlaznih parametara koji se koriste u kalkulacijama i zahteva dinamički aspekt posmatranja odnosno ocenu efikasnosti za više godina.

Ključne reči: Data Envelopment Analysis, fuzzy logic, javni gradski prevoz, kvalitet transporta.

Datum prijema članka: 08. 08. 2011.

Datum dostavljanja ispravki rukopisa: 20. 08. 2011.

Datum konačnog prihvatanja članka za objavljivanje: 22. 08. 2011.

61 